\title{
THE PATTERN OF REPRODUCTION IN FEMALE COLUMBIAN BLACK-TAILED DEER, ODOCOILEUS HEMIONUS COLUMBIANUS
}

\author{
D. C. THOMAS* AND I. McT. GOWAN $\dagger$ \\ Department of Zoology, University of British Columbia, \\ Vancouver 8, British Columbia, Canada
}

(Received 20th November 1974)

Summary. Ovarian cycles and the pattern of reproduction in female black-tailed deer in British Columbia were ascertained largely through examination of the ovaries from 444 females.

Cyclic development and degeneration of single follicles of ovulatory size occurred several weeks before first ovulation. As the breeding season approached, a second or third large follicle developed in each cycle but in $48 \%$ of adult females the follicles were at different stages of maturation. Those failing to rupture at first ovulation luteinized 1 to 2 days thereafter.

The first ovulation of the season, in November, never resulted in a lasting pregnancy even though some ova were penetrated by spermatozoa and began to cleave. First ovulation was apparently 'silent' in five of seven females for their ova lacked spermatozoa.

Of sixty-one pregnant females, fifty-nine conceived at second ovulation; the other two conceived at subsequent ovulations more widely spaced than the 8- to 9-day interval between first and second ovulations. The synchrony of ovulatory cycles among adult females was such that half of them ovulated for the second time in a span of 7 or 8 days. Primary CL that formed after first ovulation grew to an average maximum volume of only about $45 \mathrm{~mm}^{3}$, whereas those originating at second ovulation grew to twice that size within 5 to 8 days. First generation CL shrank from $35 \mathrm{~mm}^{3}$ to $10 \mathrm{~mm}^{3}$ within 2 days. They disappeared within 18 months but corpora albicantia persisted for the life of the female.

The possible ecological significance of the reproductive pattern is discussed.

\section{INTRODUCTION}

More information is needed on the nature and evolution of reproductive cycles in wild species.

Columbian black-tailed deer are polytocous, multiovular, spontaneous ovulators that breed during the autumn. The length of the oestrous cycle in

* Present address: Canadian Wildlife Service, 2721 Highway 31, Ottawa, Ganada.

$\uparrow$ Present address: Faculty of Graduate Studies, University of British Columbia, Vancouver, Canada. 
captive females is between 22 and 29 days. The majority of fawns are born in June after a gestation period of about 203 days. Most females produce one fawn when they are 2 years old, and one or two annually thereafter. These details are from Cowan (1956), Brown (1961), West (1968) and Thomas (1970). Herein, we describe the essential features of the ovarian cycle in wild female blacktailed deer (Odocoileus hemionus columbianus).

\section{MATERIALS AND METHODS}

\section{Collection of material and histological technique}

Ovaries from 444 black-tailed deer were obtained between 1963 and 1967. Most of the deer were killed by hunters in November and early December, a period coinciding with the breeding (mating) season in the $350 \mathrm{~km}^{2}$ study area on Vancouver Island, British Columbia. The ovaries were fixed in Bouin's fluid within $5 \mathrm{hr}$ of the female's death. The tissues were then dehydrated, cleared in methyl benzoate and benzene, embedded and sectioned at $10 \mu \mathrm{m}$. Every tenth or twentieth section was mounted on a slide and stained in Masson's trichrome.

In the serial sections, volumes of all CL, structures derived from degenerate CL, and large follicles were measured microscopically by two methods. Volumes of near-spherical structures were calculated from the formula $\mathrm{V}=$ $4 / 3 \pi\left(r_{1} r_{2} r_{3}\right)$, in which $r_{1}, r_{2}, r_{3}$ were the radii of the three dimensions. Diameters in two dimensions were obtained in a mid-section of a particular structure and the third was obtained from section numbers, thickness and interval. Volumes of non-spherical structures were obtained by the grid method in which $\mathrm{V}=\mathrm{Ad}$. The area (A) was determined at intervals throughout the structure and depth (d) was the interval between the sections in which A was determined.

Oviducts from periovulatory females were sectioned, stained in Masson's trichrome and examined for the presence of spermatozoa and ova. After the first year, oviducts were tied at both ends, before fixation in neutral formalin or ethanol-formalin-acetic acid, to preclude flushing of ova upon immersion in the fixative.

Using a syringe and saline solution, ova were flushed from the fresh oviducts and uteri of eleven females. After examination of the ova for stage of segmentation, presence of spermatozoa, and other cytological features, they were transferred by pipette to a well slide, stained in dilute toluidine blue and viewed again at higher magnification.

Vaginal smears were obtained by passing a slide over the surface of the vaginal epithelium near the cervix. The smears remained in equal parts of ether and $95 \%$ ethanol until stained in Harris' haematoxylin and the Schorr III stain (De Neff, 1965).

\section{Estimating the age of ovarian structures}

The timing of events for the first few days after second ovulation was estimated from the cleavage stage of nineteen spermatozoa-covered ova obtained from thirteen females. We assumed that fertilized ova in deer segmented at about the same rate as those in goats, sheep, and cattle, species that resemble 
deer more closely in their mode of reproduction than others for which cleavage stages are known. The approximate rate in these species (Clark, 1934; Winters, Green \& Comstock, 1942; Amoroso, Griffiths \& Hamilton, 1942; Hamilton \& Laing, 1946) is as follows: one cell at 0 to 1 days after ovulation, two at $1 \frac{1}{2}$, four to eight at 2 , nine to sixteen at 3 , seventeen to sixty-four at 4 and sixty-five to 128 at 5. Using this schedule of segmentation, standard volumetime curves were constructed for: (1) growth of CL derived from second ovulation, (2) degeneration of first-generation CL, (3) ratio of the above volumes, and (4) growth of third-cycle follicles.

In addition, histological characteristics of the above structures in the thirteen females were described. These quantitative and qualitative criteria were then used to estimate the stage in the reproductive cycle of other females that had ovulated for the second time shortly before their death.

Cycle chronology after the first ovulation of the season was more difficult to establish because ova released at the first ovulation were either not fertilized or, if fertilized, soon ceased to develop. Time-development criteria established for structures present after second ovulation were applied to those present after first ovulation. We assumed that rates of growth and development of first-andsecond generation CL for the first 2 to 3 days were equal, as were rates of growth and development of follicles for the first 5 to 7 days after the respective ovulations.

\section{Classification of large follicles}

Follicles were classified into ten stages based on a complex of characteristics briefly outlined below.

Active. Highly vascular, spheroid follicle with cell divisions in the mural granulosa and with clear follicular fluid, staining intensely with aniline blue.

Transitional. Moderately vascular follicle not always spheroid; follicular fluid moderately stained; cell divisions only in cumulus oophorus; spaces at base of cumulus oophorus; oocyte nucleus condensed; outer layer (from basement membrane) of granulosa cells disorganized, hyperchromatic, and some contain pyknotic nuclei; columnar cells containing polar nuclei occur in the mural granulosa.

Atresia 1. Blood vessels shrunken; follicular fluid weakly stained; follicle misshapen by other follicles or GL; cell divisions only in corona radiata; fibres and abnormal cell and nuclear types at surface of mural granulosa; cumulus oophorus detached or nearly so; oocyte nucleus in first meiotic division; hyperchromasia of ooplasm.

Atresia 2. Avascular; follicular fluid achromatic with fine cellular detritus; no cell divisions; thin reticular network of fibres at surface of mural granulosa; cytolysis or degenerative changes in up to half the cells of the cumulus oophorus; first polar body present in some oocytes; zona pellucida thick; ooplasm granular and contains vacuoles.

Atresia 3 . Only $10 \%$ to $40 \%$ of the cells of the cumulus oophorus remain; a network of fibres encircles the cumulus oophorus; outer mural granulosa replaced by a thick fibrous network which contains cell detritus and clumped degenerate cells; only one layer of normal cells persists in the mural granulosa. 
Atresia 4. Former cumulus oophorus is a coagulum of fibres and cell detritus; only small clumps of degenerate cells remain; oocyte nuclei are undergoing or have completed the second meiotic division; a thin layer of cells, sometimes radially arranged, encircles the oocyte; ooplasm is vacuolated, and hyperchromatic.

Atresia 5. Scattered small clumps of cells persist from the former cumulus oophorus; one layer of cells encircles the oocyte; some oocytes in second meiotic division; lumen shrunken, contains cell detritus.

Atresia 6 . Hyalin tissue has largely replaced the former follicular wall, which has thickened around a shrunken lumen; oocyte is denuded of granulosa cells.

Atresia 7. A large mass of hyalin tissue surrounds a small lumen.

Atresia 8 . Only a small mass of hyalin tissue persists.

\section{RESULTS}

Development of large follicles before first ovulation

The ovaries of some yearlings ( 1 to 2 years old) and all adults ( $>2$ years) collected in October and November contained one to five follicles that were greater than $30 \mathrm{~mm}^{3}$. Of the preovulatory yearlings and adults, $11 \%$ and $62 \%$ respectively, had two follicles $>30 \mathrm{~mm}^{3}$, and $61 \%$ and $31 \%$ had one follicle $>30 \mathrm{~mm}^{3}$. These figures paralleled ovulation and conception rates determined later: $85 \%$ of the yearlings were pregnant, $10 \%$ with twins; $96 \%$ of adults conceived, $70 \%$ with twins.

\section{Characteristics of large follicles just before first ovulation}

'First-cycle' follicles in females approaching first ovulation of the season ranged in volume from 20 to $100 \mathrm{~mm}^{3}$. If two or three large follicles developed, they were often out of phase. Only in twenty-one of forty adults were two large follicles in the same stage. Usually, the two follicles were out of phase by only two stages but some differed by as many as four. Most commonly, the larger follicle was in an early stage of atresia (1,2 or 3$)$ and the chromatin in its oocyte was undergoing meiotic changes. The first polar body was present between the ooplasm and the zona pellucida of many of these matured oocytes, following completion of the first meiotic division. The second large follicle in the same pair of ovaries usually was growing or was in the transitional stage and the oocyte nucleus was in the dictyate stage.

\section{Changes in corpora lutea and follicles after first ovulation}

After first ovulation, the largest or only primary CL in each female grew to 30 to $60 \mathrm{~mm}^{3}$ and then ceased to develop. Some shrinkage and cytolysis were evident in first-generation CL just before second ovulation, but subsequently these processes accelerated greatly. Cytolysis, accompanied by nuclear karyolysis, pyknosis and karyorrhexis, generally preceded structural degeneration but a few healthy luteal cells sometimes remained in CL in advanced stages of degeneration.

At first ovulation, some large follicles failed to rupture and these invariablv 
luteinized within 2 days. The entire wall or patches of mural tissue luteinized in all follicles greater than $20 \mathrm{~mm}^{3}$ and in some smaller ones. Luteinized follicles occurred in $47 \%$ of forty-five females that had ovulated only once in that season, at least 2 days before their death.

After an ovulation, all but the smallest vesicular follicles became atretic and a new generation of follicles grew rapidly. These second-cycle follicles grew from less than $5 \mathrm{~mm}^{3}$ to ovulatory size $\left(30\right.$ to $\left.60 \mathrm{~mm}^{3}\right)$ within 5 days. Large follicles in individuals on the verge of second ovulation were synchronized in development and less variable in volume than those in females approaching first ovulation. The largest follicles in each of seven females nearing second ovulation ranged from 35 to $51 \mathrm{~mm}^{3}$ and averaged $45 \mathrm{~mm}^{3}$. The smallest one was in the ovaries of an impregnated yearling.

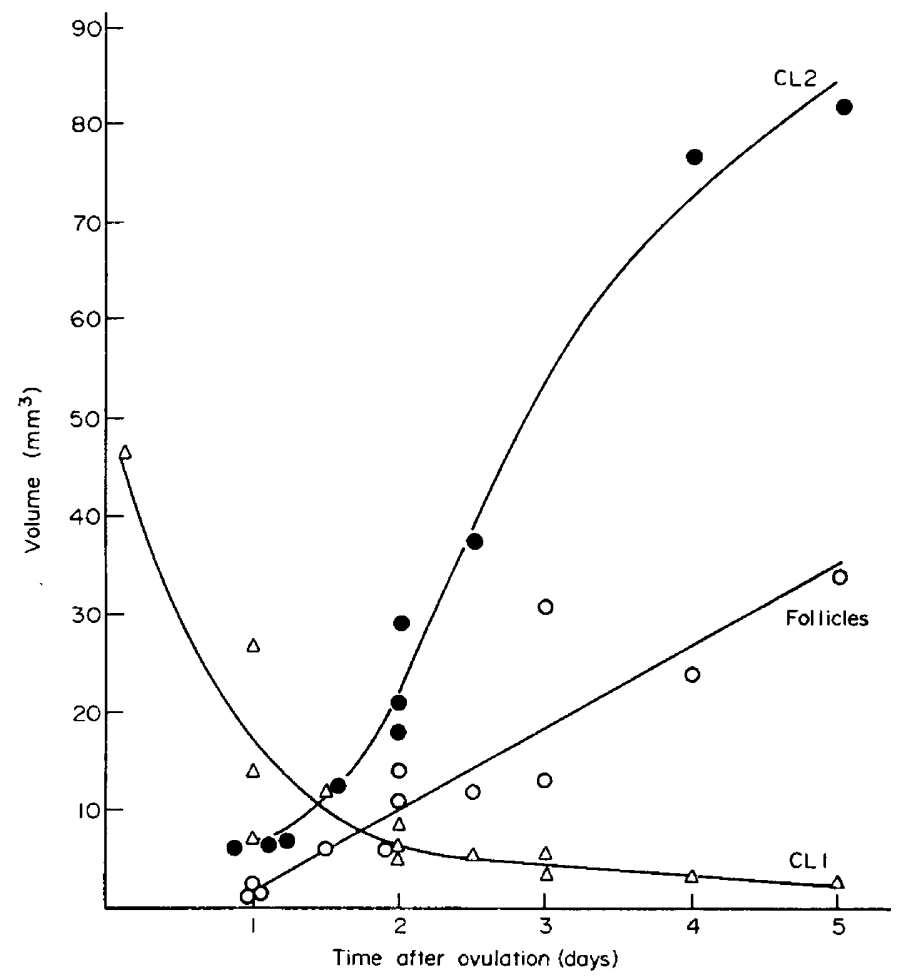

Text-Fig. 1. Temporal changes in the size of first-generation corpora lutea (CL1, $\Delta$ ), second-generation corpora lutea (GL2, $)$, and third-cycle follicles (O), after second ovulation in Columbian black-tailed deer. The time since ovulation was estimated from the cleavage stage of the ova. Each point represents the largest example of each structure in each female.

Changes in corpora lutea and follicles after second ovulation

Most adult females killed late in November had completed two ovulatory cycles. Their ovaries contained degenerate CL from the first ovulation (cyclic $\mathrm{CL}$ ) and growing CL derived from the second ovulation. Volume changes in ovarian structures after second ovulation, timed from the cleavage stage of the ova, are shown in Text-fig. 1. 
The largest second-generation CL in each female reached a volume of about $80 \mathrm{~mm}^{3}$ in 5 to 8 days. At the same time, the largest cyclic CL in each female regressed rapidly, from volumes of 30 to $45 \mathrm{~mm}^{3}$ at second ovulation to approximately $5 \mathrm{~mm}^{3}$ after 2 to 3 days and to about $2 \mathrm{~mm}^{3}$ after 7 to 8 days.

After second ovulation, luteinized follicles occurred in $11 \%$ of forty-four adults. All second-cycle follicles greater than $20 \mathrm{~mm}^{3}$ ruptured at the second ovulation, and no luteinized follicles greater than $15 \mathrm{~mm}^{3}$ were found thereafter.

A new set of follicles developed rapidly after the second ovulation, even though most females were pregnant. These 'third-cycle' follicles grew to ovulatory size in 4 or 5 days, matured, became highly vascularized and then began to degenerate about 8 to 10 days after the second ovulation. These were succeeded by 'fourth-cycle' follicles.

\section{The interval between first and second ovulations}

The interval between first and second ovulations averaged 8 to 9 days. This interval was ascertained from curves depicting the percentage of females of breeding age that had ovulated for the first and second time in samples obtained in November and early December. For example, two of forty-three females killed between 9 and 11 November in 1963 had ovulated once. By 16 to 17 November, twelve of nineteen females had ovulated once and one had ovulated twice. By 30 November, all twenty-one females had ovulated once and 13 had ovulated twice.

Table 1. November dates when $50 \%$ of Columbian black-tailed deer more than 1 year old had ovulated, based on ovulation frequency curves

\begin{tabular}{lcccrr}
\hline & 1963 & 1964 & 1965 & 1966 & 1967 \\
\hline First ovulation & 16 & 18 & 15 & 16 & 20 \\
Second ovulation & 27 & 28 & 25 & 25 & 26 \\
Interval (days) & 11 & 10 & 10 & 9 & 6 \\
Sample size & 97 & 73 & 56 & 33 & 32 \\
\hline
\end{tabular}

Curves fitted to the ovulation incidence data for $1963(\mathrm{~N}=97)$ show that $50 \%$ of the females of breeding age had ovulated for the first and second time by 16 and 27 November, respectively. Similar curves fitted to the data for 1964-67 yielded the data in Table 1. It was possible to combine the data from all five mating seasons to increase the sample size (Text-fig. 2) since there was insignificant variability in the timing of breeding between years. Differences among years was tested by analyses of variance after a correction was made for different sample sizes in different time periods. The latter was accomplished by use of a regression equation and an averaging technique. The interval between the curves for adults at ovulation incidences of $50 \%$ was 9 days. The interval was 8 days for all females of breeding age $(\mathrm{N}=298)$.

Statistics derived from frequency distributions of estimated dates of first and second ovulations (Table 2) are biassed but fiducial limits can be calculated for 
mean dates of each ovulation and the interval between them. The mean date of first ovulation in 1963 was between 15 and 20 November; that of second ovulation between 21 and 24 November and the interval was 1 to 9 days (all $\left.\mathbf{P}_{\mathbf{F}}=0.95\right)$.

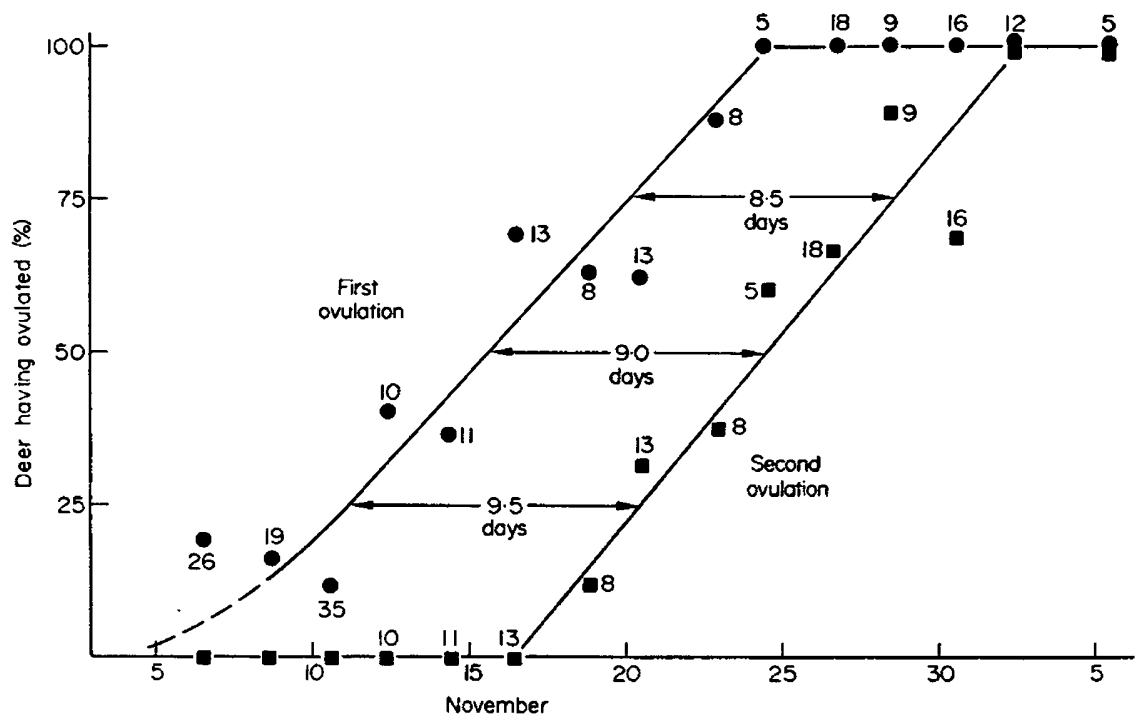

TexT-FIG. 2. The percentage of adult Columbian black-tailed deer which ovulated for the first and second time at intervals during November and early December in combined samples from five breeding seasons. Each point, accompanied by the sample size, represents pooled samples from 2 consecutive calendar days. The apparent interval in days between ovulations is estimated at ovulation frequencies of $25 \%, 50 \%$ and $75 \%$.

Table 2. Statistics derived from frequency distributions of estimated dates of first and second ovulations in Columbian black-tailed deer

\begin{tabular}{lccccc}
\hline & \multicolumn{2}{c}{1963 Data } & & \multicolumn{2}{c}{$1963-67$ Data } \\
\cline { 2 - 3 } \cline { 5 - 6 } & Ovulation 1 & Ovulation 2 & & Ovulation 1 & Ovulation 2 \\
\hline $\mathrm{N}$ & 32 & 22 & & 71 & 78 \\
$\overline{\mathrm{x}}$ & 17.4 & 22.3 & & 15.7 & 23.8 \\
$\mathrm{~S}$ & 6.9 & 3.4 & & 6.7 & 4.1 \\
$\mathrm{~S} \bar{x}$ & 1.2 & 0.7 & & 0.8 & 0.5 \\
$\mathrm{~S}-\mathrm{t}_{\text {o.0s }}$ & 2.5 & 1.5 & & 1.6 & 0.9 \\
\hline
\end{tabular}

Data biassed, see text.

Grouped data for 1963 to 1967, also biassed, show that the mean date of first ovulation fell between 14 and 17 November, that for second ovulation was between 23 and 25 November, and the interval between them fell between $5 \frac{1}{2}$ and $10 \frac{1}{2}$ days (all $\mathrm{P}_{\mathrm{F}}=0.95$ ).

The bias resulted because samples of unequal size were obtained periodically throughout the breeding season each year. In frequency distributions for first 
ovulation, the bias involved: (1) a strong over-representation of early dates, especially in 1963 when a large sample was obtained between 9 and 11 November; (2) a slight under-representation of dates in late November and early December, after the collection period, because of late ovulators, most of which were yearlings; (3) a moderate under-representation of early and mid-dates because females that had ovulated twice were not included in the distributions for the first ovulation. The net result was a biassed distribution moderately overrepresented by early dates and moderately under-represented in mid- and late dates. These biassed data would yield an early ( 1 or 2 days) mean date of first ovulations and would inflate the variance.

Frequency distributions for the second ovulation were biassed because early dates were moderately over-represented and late dates were under-represented moderately to strongly, depending on the year. The net result would be a distribution to the left (early) of the true distribution. Thus, the mean is probably early by 2 to 4 days and the variability may be underestimated.

As both distributions were biassed in a similar manner, differing only in degree, the calculated interval between the means is a good estimate of the real interval. The estimated average interval, 8 days, may be underestimated by 1 to 2 days because of differences in the degree of bias in the distributions for two ovulations.

\section{Synchronization of second ovulation among females}

About $50 \%$ of females $>1$ year old ovulated for the second time in a span of 8 days. Inspection of Text-fig. 2 reveals that about 50, 75 and $100 \%$ of adult females ovulated for the second time in periods of 7,11 and 15 days, respectively. The conception period was almost equally short because $97 \%$ of all females (yearlings $92 \%, \mathrm{~N}=13$; adults $98 \%, \mathrm{~N}=48$ ) conceived at the second ovulation.

\section{Ovulatory cycles before conception}

Further proof that every female underwent at least one luteal ycle before conceiving was obtained by examining the ovaries of females coliected late in the breeding season or after it. In sixty-four females killed late in the breeding season but before their embryos became visible macroscopically, there were ninety-three degenerate cyclic CL and ninety-seven active second-generation GL, a non-significant difference $(P>0.05)$. Equal numbers (one or two) of primary CL developed after the first and second ovulation in each of fifty-three females. In each of three females, the number of primary cyclic CL (two or three) exceeded the number of CL produced at second ovulation; in eight females, the reverse was true. Similarly, all forty-seven females with macroscopically visible embryos contained degenerate cyclic CL.

The ovaries of two of sixty-one pregnant females contained more than one generation of degenerate cyclic CL. A yearling killed on 6 May contained one GL of pregnancy and three regressed cyclic CL; at a frequency of one $\mathrm{CL} / \mathrm{cycle}$, this female conceived after her fourth ovulation. The other female, an adult killed on $7 \mathrm{May}$, contained two CL of pregnancy and seven degenerate cyclic CL. The latter structures could not be confused with degenerate luteinized 
follicles or other accessory CL because the hyalinized structures could be traced to the surface of the ovary where scar tissue usually marked the point of rupture. At an average frequency of $1.75 \mathrm{CL}$ each ovulatory cycle, this female conceived after her fifth ovulation. Thus, the calculated mean interval between ovulatory cycles subsequent to the second in each female was, respectively, 23 and 12 days. These figures are based on mean dates of second ovulation and estimated dates of conception, the latter from fetal growth curves.

\section{Failure of eggs shed at first ovulation}

Of eight eggs recovered from seven females, only two from separate females had spermatozoa on their zona pellucida. The latter ova contained five and six cells, stages normally attained in mammals within 2 days of ovulation, but segmentation had slowed or ceased because the associated CL were characteristic of ones 4 to 6 days old. Spermatozoa were not detected in the vaginal smears or oviducts of periovulatory females, but were found in both locations just before and for a day or two after the second ovulation.

\section{Ovarian changes in pregnant females}

Primary CL obtained at three periods during the first 4 months of gestation averaged 78 to $88 \mathrm{~mm}^{3}$. In May and early June, the mean volumes were significantly $(P<0.05)$ larger: $118(\mathrm{~N}=16)$ and $130\left(\mathrm{~N}=10 \mathrm{~mm}^{3}\right)$, respectively. By mid-June, a few days after parturition, they had shrunk to less than $1 / 5$ former volumes. The resultant corpora albicantia persisted in the ovaries for the life of the females.

Cyclical growth and degeneration of follicles continued throughout pregnancy although there was reduced activity at mid-pregnancy in February and March. The mean volume of the largest follicle increased from $22 \mathrm{~mm}^{3}$ in February and March $(\mathrm{N}=19)$ to $46 \mathrm{~mm}^{3}$ in May and June $(\mathrm{N}=22)$. Follicles as large as $80 \mathrm{~mm}^{3}$ developed in the last few weeks of gestation. Some large follicles ruptured throughout gestation but no luteal tissue developed. By contrast, there was negligible follicular activity in the only non-pregnant adult female, killed in May, although several sets of degenerate cyclic CL indicated earlier follicular activity.

After the second ovulation, cyclic CL degenerated into distinctive hyalinized scars that persisted throughout pregnancy. Shrinkage of the scars was gradual but continuous from November to March, after which their volumes averaged $0.05 \mathrm{~mm}^{3}$. Complete resorption of these scars occurred 6 to 18 months after their initial formation.

\section{Annual ovarian changes}

The typical changes in ovarian structures associated with the annual breeding season are summarized in Text-fig. 3 .

Cyclical growth and atresia of several sets of large follicles occurred before first ovulation. Their cycle length, the interval between the onset of degeneration of two consecutive groups of large follicles, was assumed to be the same as that of cycles after first ovulation, i.e. 8 or 9 days. 


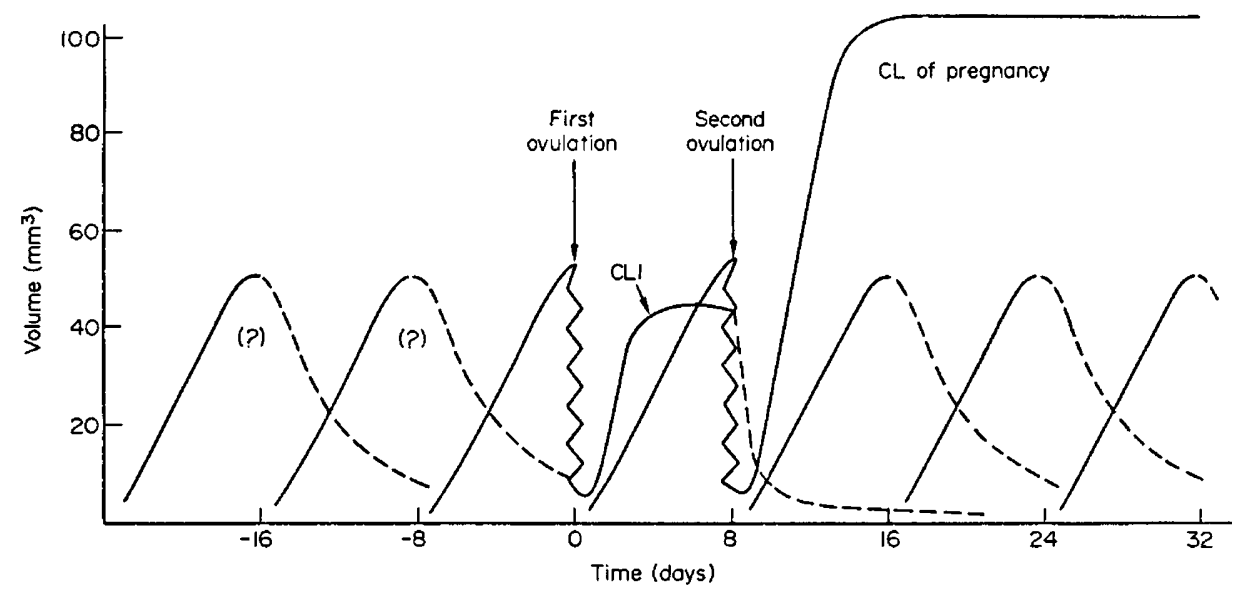

TEXT-FIG. 3. Representation of temporal changes in the size of follicles and corpora lutea during the breeding season of Columbian black-tailed deer. The length of follicular cycles before first ovulation (?) is not known.

\section{DISGUSSION}

One significance of rapid follicular growth and short follicular cycles, seemingly independent of luteal function or embryonic development, is a short interval between ovulations. Corner (1921) and Hammond (1927) believed that tertiary follicles in the pig and cow, respectively, gradually grew to ovulatory size over a period of two or three oestrous cycles. By contrast, Loeb (1911), in guinea-pigs, and Bane \& Rajakoski (1961), in cattle, suggested there were two phases of follicular growth within oestrous cycles. Follicular cycles probably occur within oestrous cycles in black-tailed deer if conception does not occur at second ovulation.

Oestrous cycles of two or more lengths almost certainly exist in black-tailed deer. If conception does not ensue at second ovulation, follicular cycles 8 to 9 days in length may continue with ovulation and oestrus occurring every second or third follicular cycle depending on the functional life of associated CL. Oestrus every third follicular cycle would explain copulatory or oestrous behaviour at intervals of 23 to 29 days in confined Odocoileus spp. (Cheatum \& Morton, 1942; Cowan, 1956; Haugen, 1959; West, 1968). The Uganda kob exhibited copulatory cycles of 20 to 26 days and 12 to 13 days (Buechner, Morrison \& Leuthold, 1966), and some female sexual activity, i.e. visits to male's territory without copulation, was observed at intervals of 5 to 7 days. Morrison \& Buechner (1971) state that many oestrous periods in kob recur at intervals of 6 to 13 days.

Infertile and 'silent' first ovulations of each season represent a mechanism that probably increases the pregnancy rate. Asynchronous development of follicles and oocytes before first ovulation would result in a low conception rate if lasting pregnancies ensued. The accompaniment of first ovulation by oestrus in some females and not in others could be explained if increasing levels of one or more of the gonadotrophic hormones was needed for: (1) ovulation, 'silent' heat, and development of small CL (first ovulation, some females); (2) ovulation, oestrus, 
development of small CL, and fleeting pregnancy (first ovulation, some females); (3) ovulation, oestrus, development of large CL and pregnancy in most (second ovulation, all females).

The oestrus occurring at first ovulation in a small proportion of females, which results in copulation, apparent fertilization, and early resorption, seems to serve no purpose, but the oestrous females may stimulate one or both sexes and contribute to synchrony of breeding. The reason why fertilized ova fail after first ovulation is not known but insufficient progesterone is a possibility.

Progesterone secreted by the small first-generation corpora lutea may have a 'priming' effect, as described in sheep by Robinson (1959), so that all females come into oestrus at or just before second ovulation. Other species in which one luteal cycle is necessary before lasting pregnancy ensues include some sheep (Robinson, 1959), African elephants (Loxodonta africana: Short, 1966) and Uganda kob antelope (Adenota kob: Morrison \& Buechner, 1971). 'Silent' heats are not uncommon in domestic animals attaining sexual maturity and have been suggested for kob (Buechner et al., 1966), elk (Cervis canadensis: Morrison, 1960), moose (Alces alces: Simkin, 1965) and African elephants (Perry, 1953). They are often associated with shortened cycles, small $\mathrm{CL}$ and low progesterone levels, as in some dairy cows after parturition (Pope, Gupta \& Munro, 1969).

The short interval between ovulations, the high proportion of females conceiving at second ovulation, the short conception period among females and the regularity in timing of breeding seasons suggest adaptations, in the species investigated or its ancestors, to a restricted optimal period for the birth of young.

\section{ACKNOWLEDGMENTS}

This study was supported financially by the University of British Columbia, the National Research Council of Canada, Canadian Industries Limited, the Canadian Wildlife Service and the British Columbia Fish and Wildlife Branch. We thank Ms J. Mary Taylor for suggesting improvements and $\mathrm{Mr}$ A. L. Wilson for statistical analyses.

\section{REFERENCES}

Amoroso, E. G., Griffiths, W. F. B. \& Hamilton, W. J. ( 1942) The early development of the goat. 7. Anat. 76, 377-406.

Bane, A. \& Rajakoski, E. (1961) The bovine estrous cycle. Cornell Vet. 51, 77-95.

Brown, E. R. (1961) The Black-Tailed Deer of Western Washington. Washington State Game Dept., Biol. Bull. No. 13.

Buechner, H. K., Morrison, J. A. \& Leuthold, W. (1966) Reproduction in the Uganda kob with special reference to behaviour. Symp. zool. Soc. Lond. 15, 69-88.

Gheatum, E. L. \& Morton, G. H. (1942) Techniques used in determining the period of the rut among white-tailed deer in New York State. Trans. $\mathcal{N}$. Am. Wildl. Conf. 7, 334-342.

CLARK, R. T. (1934) Studies on the physiology of reproduction in the sheep. II. The cleavage stages of the ovum. Anat. Rec. 60, 135-159.

Gorner, G. W. (1921) Gyclic changes in the ovaries and uterus of the sow and their relations to the mechanisms of implantation. Contrib. Embryol. 13, 119-146.

Gowan, I. McT. (1956) Life and times of the coast black-tailed deer. In The Deer of North America. Ed. W. P. Taylor. Wildl. Mgmt Inst., Washington, D.G.

De Nefr, J. G. (1965) Clinical Endocrine Cytology. Harper \& Row, New York.

Hamilton, W. J. \& LaING, J. A. (1946) Development of the egg of the cow up to the stage of blastocyst formation. F. Anat. 80, 194-204. 
Hammond, J. (1927) Physiology of Reproduction in the Cow. Cambridge University Press, London.

Haugen, A. O. (1959) Breeding records of captive white-tailed deer in Alabama. F. Mammal. 40, 108113.

LoEB, L. (1911) The cyclic changes in the ovary of the guinea-pig. F. Morph. 22, 37-70.

Morrison, J. A. (1960) Ovarian characteristics of elk of known breeding history. F. Wildl. Mgmt, 24, 297-307.

Morrison, J. A. \& Buecriner, H. K. (1971) Reproductive phenomena during the post partumpreconception interval in the Uganda kob. F. Reprod. Fert. 26, 307-317.

Perry, J. S. (1953) The reproduction of the African elephants, Loxodonta africana. Phil. Trans. R. Soc. B, 237, 93-149.

Pope, G. S., Gupta, S. K. \& Munro, I. B. (1969) Progesterone levels in the systemic plasma of pregnant, cycling and ovariectomized cows. F. Reprod. Fert. 20, 369-381.

Robinson, T.J. (1959) The estrous cycle of the ewe and doe. In Reproduction in Domestic Animals, Vol. 1. Eds. H. H. Cole and P. T. Cupps. Academic Press, New York.

Short, R. V. (1966) Oestrous behaviour, ovulation and the formation of the corpus luteum in the African elephant (Loxodonta africana). E. Afr. Wildl. J. 4, 56-68.

Simkin, D. W. (1965) Reproduction and productivity of moose in Northwestern Ontario. F. Wildl. Mgmt, 29, 740-750.

Thomas, D. C. (1970) The ovary, reproduction and productivity of female Columbian black-tailed deer. Ph.D. thesis, University of British Golumbia, Vancouver.

WEst, N. O. (1968) The length of the oestrous cycle in the Columbian black-tailed deer or coast deer (Odocoileus hemionus columbianus). B.Sc. thesis, University of British Columbia, Vancouver.

Winters, L. M., Green, W. W. \& Comstock, R. E. (1942) Prenatal development of the bovine. Tech. Bull. Minn. agric. Exp. Stn, No. 151. 